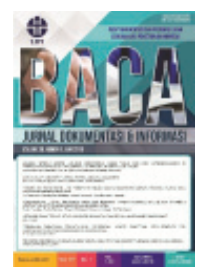

\title{
KETERAMPILAN LITERASI INFORMASI MAHASISWA MENURUT STANDAR KOMPETENSI LITERASI INFORMASI ASSOCIATION OF COLLEGE \& RESEARCH LIBRARIES (ACRL)
}

\author{
Djoko Prasetyo $^{1^{*}}$, Fathu Rahman Rosyidi ${ }^{2}$, Rohmadi $^{3}$, Uswatun Auliyani ${ }^{4}$, Sri Handayani ${ }^{5}$ \\ ${ }_{1,3,5}$ UPT Perpustakaan, Universitas Jenderal Soedirman \\ ${ }^{2,4}$ Pusat Informasi Ilmiah Fakultas Pertanian, Universitas Jenderal Soedirman \\ *Korespondensi: dprasta@yahoo.co.id
}

Diajukan: 03-11-2017; Direview: 30-11-2017; Diterima: 08-02-2018; Direvisi: 15-03-2018

\begin{abstract}
The research on the analisis of information literacy skills of undergraduate students of Universitas Jenderal Soedirman by using standards of information literacy competency ACRL has been conducted. It is aimed to know the literacy skill of undergraduate students of bacth 2014 and 2015. The skills include determination of the nature and scope of the required information; ability of access the information needed effectively and efficiently; evaluation of information and sources critically; capability of using the information to accomplish particular purposes; and understanding of economic, legal, and social aspects which are related to the use of information. This is a descriptive research with samples of undergraduate students of Unsoed as many as 334 students among 7,376 students. Thus, one variable analysis is used in order to see the value of the central tendency and then tested by using the rate value. The results showed that students' information literacy skills measuring by the standard information literacy competency standards for higher education from ACRL are in the skilled category. Some standards need to be improved, e.g., the competency standard in determination of the nature and scope of the information which has the lowest score of 3,73 . The others, the standard of competence to access information effectively and efficiently, with an average score of 3,88 as well as the competence standard to evaluate the information and its sources, with an average score of 3,84 are also need to be improved.
\end{abstract}

\begin{abstract}
ABSTRAK
Penelitian dengan judul analisis keterampilan literasi informasi mahasiswa S1 Universitas Jenderal Soedirman dengan menggunakan Standar Kompetensi Literasi Informasi dari ACRL. Penelitian ini bertujuan untuk mengetahui keterampilan literasi informasi mahasiswa S1 Angkatan 2014 dan 2015. Ketrampilan yang dimaksud meliputi kemampuan menentukan sifat dan cakupan informasi yang dibutuhkan; mengakses informasi yang dibutuhkan secara efektif dan efisien; mengevaluasi informasi dan sumber-sumbernya secara kritis; menggunakan informasi untuk menyelesaikan tujuan tertentu; memahami aspek ekonomi, hukum, dan sosial yang berkaitan dengan penggunaan informasi. Penelitian ini menggunakan metode deskriptif dengan mengambil sampel mahasiswa S1 sejumlah 334 orang mahasiswa dari 7376 orang mahasiswa. Analisis peneliltian ini merupakan analisis satu variabel dengan melihat nilai kecenderungan centralnya. Pengujian dalam penelitian ini menggunakan nilai rata-rata. Hasil penelitian menunjukkan bahwa keterampilan literasi informasi mahasiswa yang diukur mengggunakan the standard information literacy competency standards for higher education dari ACRL dalam kategori terampil. Dari pengukuran kelima standar keterampilan literasi informasi terdapat beberapa standar yang perlu ditingkatkan, seperti standar kompetensi untuk menentukan sifat dan cakupan informasi mendapat skor rata-rata yang paling rendah, yaitu 3,73. Demikian halnya dalam standar kompetensi untuk mengakses informasi secara efektif dan efisien, dengan skor rata-rata 3,88. Pada standar kompetensi yang ketiga, yaitu standar kompetensi untuk mengevaluasi informasi dan sumber-sumbernya juga diperoleh skor rendah dengan rata-rata 3,84 .
\end{abstract}

Keywords: Information literacy; Literacy skill; Literacy standards; ACRL; Students; Higher education 


\section{PENDAHULUAN}

Perkembangan teknologi informasi yang berdampak pada perkembangan informasi menyebabkan terjadinya ledakan informasi. Informasi yang sangat melimpah tidak semuanya dapat dimanfaatkan sepenuhnya. Informasi sudah masuk dalam berbagai kehidupan manusia, penguasaan informasi akan membawa seseorang memiliki keunggulan kompetitif. Hal tersebut sangat dirasakan oleh individu yang bergerak dalam bidang pendidikan dan penelitian seperti halnya mahasiswa. Mahasiswa di perguruan tinggi tidak terlepas dari tugas-tugas berupa pembuatan karya ilmiah, seperti makalah, artikel, atau tugas akhir studi.

Terdapat beberapa aspek yang harus dipenuhi oleh informasi agar dapat digunakan dan dimanfaatkan, yaitu informasi yang berkualitas. Kualitas suatu informasi, menurut Sutabri (2014) tergantung dari tiga hal, yaitu informasi harus akurat (accurate), tepat waktu (timeliness), dan relevan (relevance). Informasi yang berkualitas yang dimanfaatkan hingga termanifestasikan dalam bentuk pengambilan keputusan atau untuk pemecahan masalah merupakan proses literasi informasi.

Kemampuan untuk memenuhi kebutuhan informasi tidak muncul dengan sendirinya. Kemampuan untuk mendapatkan informasi merupakan kemampuan yang dimiliki oleh setiap orang, namun dalam tingkat kemampuan yang berbeda-beda. Tingkatan kemampuan akan menentukan seberapa baik hasil dari analisis informasi yang ditemukan, hal tersebut sangat berpengaruh terhadap produk informasi yang dihasilkan mahasiswa.

Perkembangan dalam deseminasi informasi saat ini mempunyai tren sendiri melalui berbagai media. Mahasiswa dituntut mengikuti perkembangan iptek agar mendapatkan informasi yang sebaik-baiknya untuk mengerjakan tugas-tugas perkuliahan. Qalyubi (2007) mengatakan bahwa seseorang harus senantiasa berubah dan berorientasi ke depan, menjadi individu modern yang menjembatani transisi. Di era informasi ini keterampilan literasi informasi sangat diperlukan.

Istilah literasi informasi digunakan Zurkowsky pada saat mengajukan proposal kepada The National Commision on Libraries and Information Science (NCLIS) tahun 1974. Menurut Zurkowsky dalam Dangi \& Saraf (2016), orang yang literasi informasi merupakan orang yang terlatih dalam penerapan sumber daya informasi. Dahulu makna literasi hanya sebatas mengenal huruf dan dapat membaca. CILIP (2013) memberikan batasan tentang literasi informasi sebagai "information literacy is knowing when and why you need information, where to fine it and how to evaluate, uses and communicated it an ethical manner". Pernyataan tersebut menggambarkan bahwa orang yang literate akan mengetahui kapan dan mengapa memerlukan informasi; di mana dapat memperoleh informasi; dan bagaimana mengevaluasi informasi, memanfaatkan dan mengkomunikasikannya secara etis.

American Library Association (ALA) menyatakan bahwa seseorang memiliki keterampilan literasi informasi jika orang tersebut menyadari kapan memerlukan informasi dan mempunyai kemampuan untuk menemukan, mengevaluasi, dan menggunakan secara efektif informasi tersebut. Berdasarkan pernyataan Association of College and Research Libraries $(A C R L)$, keterampilan literasi informasi mahasiswa dapat diukur dengan lima indikator standar, yakni sebagai berikut.

1) Menentukan sifat dan cakupan informasi. Pengukuran indikator ini menggunakan empat aspek terkait dengan keterampilan dalam merumuskan langkah, yaitu merumuskan lebih dulu langkah untuk mendapatkan informasi serta mengidentifikasi jenis dan ragam format informasi, seperti audio visual, multi media, website, buku, dan bahan perpustakaan lainnya. Dalam mencari informasi mestinya mempertimbangkan antara biaya dan 
keuntungan yang diperoleh untuk mendapatkan informasi, perlu dilakukan evaluasi kembali sifat dan cakupan informasi yang diperoleh sudah sesuai atau belum.

2) Mengakses informasi yang efektif dan efisien. Indikator ini terdiri dari lima aspek terkait keterampilan memilih metode penelusuran dan sistem temu kembali informasi yang paling tepat serta penggunaan strategi penelusuran (boolean operator, truncation, dsb). Dalam penelusuran online menggunakan membatasi URL dan tipe dokumen, serta memiliki kemampuan untuk mengutip, mencatat, dan mengelola sumber-sumber informasi.

3) Mengevaluasi informasi dan sumber-sumbernya secara kritis. Dalam hal ini, akan diukur keterampilan dalam meringkas ide utama yang dikutip. Beberapa aspek yang dievaluasi mencakup keterampilan untuk menentukan dan menggunakan kriteria awal; keterampilan mengumpulkan ide utama dari informasi yang diperoleh untuk membangun konsep baru; membandingkan pengetahuan baru dengan pengetahuan terdahulu untuk menentukan nilai tambah, kontradiksi, nilai karakteristik unik dari sebuah informasi. Evaluasi informasi dapat dilakukan melalui diskusi dengan orang lain, para ahli atau dosen dalam pembuktian kebenaran, pemahaman, dan interpretasi informasi.

4) Menggunakan informasi untuk tujuan tertentu. Indikator ini merupakan keterampilan dalam menggunakan informasi untuk menyelesaikan pekerjaan. Dalam hal ini, diperlukan kemampuan menggunakan informasi baru dan terdahulu untuk merencanakan dan menghasilkan karya. Meninjau kembali proses dalam penyusunan karya tulis dan mengkomunikasikan hasil karya dengan memilih media yang tepat serta terampil dalam menggunakan reference manager dalam proses pembuatan karya tulis.

5) Memahami aspek ekonomi, hukum, dan sosial terkait penggunaan informasi. Hal ini terkait dengan isu privasi dan keamanan, hak akses informasi, sensorship, hak kekayaan intelektual, dan hak cipta. Hak akses terhadap sumber informasi terbatas pada orang tertentu saja dan orang lain dapat mengakses namun harus ada izin khusus. Privasi dan keamanan sumber informasi tidak dapat diakses oleh setiap orang. Etika menjadi suatu hal yang sangat penting dalam pemanfataan informasi, seperti pengakuan terhadap penggunaan sumber informasi yang disitir atau dikutip.

Penelitian ini bertujuan untuk mengetahui keterampilan literasi informasi yang dimiliki oleh mahasiswa Universitas Jenderal Soedirman (selanjutnya disebut mahasiswa Unsoed), yang mencakup: 1) menentukan sifat dan cakupan imformasi yang dibutuhkan; 2) mengakses informasi yang dibutuhkan secara efektif dan efisien; 3) mengevaluasi informasi dan sumbersumbernya secara kritis; 4) menggunakan informasi untuk tujuan tertentu; dan 5) memahami aspek ekonomi, hukum, dan sosial berkaitan dengan penggunaan informasi. Adapun rumusan masalah penelitian ini, yaitu bagaimana keterampilan literasi informasi mahasiswa Unsoed menurut standar kompetensi literasi informasi untuk perguruan tinggi ACRL? Hal tersebut dijelaskan pada bagian hasil dan pembahasan penelitian ini.

\section{TINJAUAN PUSTAKA}

\subsection{Literasi Informasi}

Pada tahun 1974 President of the US Information Industry Association, Paul Zurkowski, mengajukan proposal kepada NCLIS. Zurkowski berpendapat bahwa "orang-orang yang terlatih dalam penerapan sumber daya informasi disebut literate information (Septiyantono, 2014). Makna literasi berkembang luas, jika zaman dahulu literasi dimaknai sebagai orang yang mengenal huruf atau menjelaskan orang yang memiliki kemampuan membaca dan 
menulis, saat ini terdapat makna lain yang lebih dari yang telah disebutkan di atas (Sudarsono, 2009).

Di Indonesia, literasi informasi diartikan sebagai keberinformasian. Di Inggris, Chartered Institute of Library and Information Professional memberikan batasan literasi informasi sebagai "knowing when and why you need information, where to fine it, and how to evaluate, uses and communicated it an ethical manner". Literasi informasi menyangkut seperangkat keterampilan untuk memecahkan masalah atau untuk membuat keputusan, baik untuk kepentingan akademis maupun pribadi, yang melalui proses pencarian, penemuan, dan pemanfaatan informasi dari beragam sumber serta mengkomunikasikan pengetahuan baru tersebut secara efisien, efektif, dan beretika (George 2014). Martin Tessmer dalam Septiyantono (2014) mengatakan bahwa literasi informasi merupakan kemampuan untuk mengakses secara efektif dan mengevaluasi informasi untuk kebutuhan pokok.

Keterampilan literasi informasi seharusnya dimiliki oleh setiap sivitas akademik agar dalam proses pendidikan, penelitian, dan pengabdian kepada masyarakat dapat menemukan informasi yang dibutuhkan secara cepat dan tepat serta mampu mengevaluasi informasi. CILIP (2013) menyatakan bahwa seseorang yang literet informasi akan mengetahui kapan memerlukan informasi, mengapa memerlukan informasi, kemana mencari informasi, bagaimana mengevaluasi informasi, bagaimana menggunakan informasi, dan bagaimana mengkomunikasikan informasi. Dapat dikatakan bahwa orang yang berinformasi adalah seseorang yang memenuhi enam kriteria di atas (Sudarsono 2009).

Lebih lanjut, Doyle (1992) mengatakan beberapa kriteria seseorang dikatakan literet informasi, yaitu: (1) menyadari kebutuhan informasi; (2) menyadari informasi yang akurat dan lengkap merupakan satu dasar untuk membuat keputusan; (3) mengidentifikasi sumbersumber potensial dari suatu informasi; (4) membangun strategi pencarian yang tepat; (5) mengakses sumber-sumber informasi termasuk dasar teknologi lainnya; (6) mengevaluasi informasi; (7) mengorganisasikan informasi untuk mengaplikasikan/mempraktikan; (8) mengintegrasikan informasi yang baru dengan yang sudah dimiliki (pengetahuan lama); dan (9) menggunakan informasi dengan kritis dan untuk menyelesaikan masalah.

\subsection{Literasi Informasi di Perguruan Tinggi}

Informasi menjadi kebutuhan semua orang tetapi tidak semua orang dapat menemukan dan memanfaatkan informasi secara efektif, efisien, dan beretika. Hal tersebut juga berlaku keterampilan literasi informasi bagi mahasiswa. Perguruan tinggi merupakan lembaga yang memiliki misi mengembangkan pembelajar seumur hidup guna menghasilkan sumber daya manusia yang berkualitas. Literasi informasi membentuk dasar pembelajaran seumur hidup, hal ini berlaku bagi semua disiplin, lingkungan, dan lingkungan belajar, serta semua tingkatan pendidikan.

Hasugian (2008) mengatakan bahwa dengan literasi informasi, mahasiswa dapat menguasai isi materi dan memperluas penelitian, mengarahkan diri sendiri, serta memiliki kontrol yang lebih besar terhadap proses pembelajaran. Proses pembelajaran di perguruan tinggi memerlukan banyak sumber informasi, mahasiswa akan mendapatkan tugas-tugas yang diberikan oleh dosen. Mahasiswa memerlukan sumber-sumber informasi yang berkualitas untuk menyelesaikan tugas-tugas yang diberikan oleh dosen agar menghasilkan hasil yang berkualitas. Perguruan tinggi sebagai lembaga yang mengembangkan pembelajar seumur hidup harus memastikan bahwa mahasiswa memiliki kemampuan intelektual penalaran dan berpikir kritis. 


\subsection{Penelitian Terdahulu}

Penelitian yang dilakukan oleh Bahar, Sismita, dan Purnomowati (2006) dalam Pattah (2014) terhadap 94 tenaga pendidik dan kependidikan pendidikan non-formal provinsi DKI Jakarta. Penelitian ini menggunakan metode pendekatan kuantitatif dengan mengunakan kuesioner untuk mengumpulkan datanya disertai dengan wawancara mendalam. Hasil temuannya hanya $19,71 \%$ pada taraf mengetahui kebutuhan informasi atau cara mengakses informasi dan mampu mengevaluasi informasi dan menggunakan informasi. Mereka belum memiliki kemampuan untuk mengelola informasi, menggunakan informasi untuk membuat konsep baru, menciptakan sebuah pemahaman baru, dan pemahaman aspek budaya, sosial, dan ekonomi serta hukum dalam penggunaan informasi. Ketika mencari informasi, mereka masih mengandalkan cara-cara tradisional dan menggunakan teknologi informasi masih menggunakan prioritas terakhir.

Penelitian yang dilakukan oleh AL Hamidy \& Heriyanto (2012) tentang "Kemampuan Literasi Informasi Mahasiswa pada Layanan American Corner di UPT Perpustakaan IAIN Walisongo Semarang menurut ACRL". Apriyanti (2010) dalam Pattah (2014) mengkaji tentang literasi informasi pemustaka di perpustakaan umum daerah provinsi DKI jakarta. Penelitian ini menggunakan pendekatan kualitatif dengan metode studi kasus. Hasil menunjukan bahwa pemustaka perpustakaan umum daerah DKI Jakarta memiliki kemampuan literasi informasi yang cukup baik. Pemustaka mampu melakukan 11 indikator kinerja dari 22 indikator kinerja yang terdapat dalam 5 komponen standar kompetensi literasi informasi ACRL.

Kemudian penelitian yang dilakukan oleh Sinurat, Zulharman, dan Amtarina (2017) tentang tentang keterampilan literasi informasi di Fakultas Kedokteran Universitas Riau. Penelitian ini menggunakan metode penelitian kualitatif dengan pendekatan fenomenologis untuk memahami esensi dari pengalaman hidup seseorang terkait konsep/fenomena. Hasil penelitian menunjukkan bahwa mahasiswa memiliki kemampuan untuk memahami kebutuhan informasi, memiliki kemampuan untuk mengakses informasi secara efektif, namun belum efisien dan belum mampu mengevaluasi sumber informasi.

\section{METODE}

Penelitian ini menggunakan metode deskriptif dengan populasi mahasiswa Unsoed angkatan 2014 dan 2015, yaitu sebanyak 7.376 (Unsoed, 2017). Penelitian ini menjelaskan situasi atau peristiwa. Penelitian tidak mencari atau menjelaskan hubungan, tidak menguji hipotesis atau membuat prediksi (Rakhmat, 2000). Menurut Nazir (2009), metode deskriptif merupakan suatu metode untuk meneliti suatu kelompok manusia, suatu objek, suatu set kondisi, suatu sistem pemikiran, atau suatu kelas peristiwa pada masa sekarang. Sugiyono (2010) mengatakan bahwa penelitian deskriptif adalah penelitian yang dilakukan untuk menilai variabel mandiri, baik satu variabel atau lebih independen tanpa membuat perbandingan ataupun menghubungkan dengan variabel lain. Peneliti hanya akan mendeskripsikan atau memaparkan data yang diperoleh dari responden yang dilaksanakan dari bulan Agustus - November 2017.

Sampel penelitian menggunakan rumus Isaac dan Michael dengan tingkat kesalahan 5\% sehingga ditemukan sampel 334. Data dianalisis menggunakan teknik analisis deskriptif, yaitu merupakan cara mendeskripsikan data yang terkumpul sebagaimana adanya (Sugiyono, 2014). Untuk mengetahui keterampilan literasi informasi mahasiswa digunakan analisis statistik deskriptif, yaitu data diberikan nilai dengan menggunakan skala likert untuk mengukur sikap, 
pendapat, dan persepsi seseorang atau kelompok orang tentang gejala atau fenomena pendidikan (Djaali, 2008).

Setelah data terkumpul, peneliti melakukan analisis data sesuai dengan tujuan penelitian (Hartinah, 2013). Analisis data dilakukan dengan membuat distribusi frekuensi masing-masing variabel penelitian, yaitu untuk menunjukkan berapa kali suatu nilai hasil pengukuran terjadi dalam seluruh pengukuran sampel. Penelitian ini menggunakan dua analisis deskriptif, yaitu:

1) Pengujian deskriptif menggunakan nilai mean

Analisis penelitian ini merupakan analisis satu variabel yang dilakukan dengan melihat nilai kecenderungan centralnya. Pengujian penelitian ini menggunakan nilai rata-rata (mean) dengan rumus (Tashakkori \& Teddlie, 2010):

$$
\mu=\frac{\sum x}{N}
$$

$$
\begin{aligned}
& \text { Keterangan: } \\
& \begin{aligned}
\mu & =\text { nilai rata-rata hitung } \\
\sum_{\mathrm{N}}^{\mathrm{x}} & =\text { jumlah semua nilai (dari kuisioner) } \\
& =\text { Jumlah responden }
\end{aligned}
\end{aligned}
$$

2) Pengujian nilai mean data kelompok keterampilan literasi informasi

Pengujian nilai mean dengan mengambil titik tengah data yang dibuat dalam distribusi frekuensi. Pengambilan titik tengah dilakukan dengan menghitung setengah dari jumlah ujung bawah kelas dan ujung atas kelas sebagai wakil dari setiap intervalnya. Dalam penghitungan mean data kelompok digunakan rumus:

$$
\mu=\frac{\sum\left(t_{1} f_{1}\right)}{\sum f_{1}}
$$

$$
\begin{array}{cl}
\text { Keterangan: } & \\
\mu & =\text { mean } \\
\mathrm{t}_{1} & =\text { titik tengah } \\
\mathrm{f}_{1} & =\text { frekuensi } \\
\sum \mathrm{f}_{1} & =\text { Jumlah frekuensi }
\end{array}
$$

Pada penelitian ini, pemaknaan terhadap skor dari masing-masing indikator keterampilan literasi informasi diperlukan penyusunan pedoman penafsiran dengan langkah-langkah (Sukiman, 2011):

1) menghitung skor terendah, untuk memperoleh skor terendah dengan mengalikan skor terendah masing-masing indikator atau aspek dengan banyaknya aspek atau indikator yang dinilai;

2) menghitung skor tertinggi, untuk memperoleh skor tertinggi dengan mengalikan skor tertinggi masing-masing indikator atau aspek dengan banyaknya indikator atau aspek yang dinilai;

3) menghitung selisih skor tertinggi dan skor terendah, untuk mendapatkan selisih skor dengan menghitung skor tertinggi dikurangi dengan skor terendah;

4) menentukan jumlah kategori yang akan digunakan untuk menafsirkan skor-kategori dalam penelitian ini terdiri dari 5 kategori, yaitu sangat trampil, trampil, cukup trampil, tidak trampil, dan sangat tidak terampil; 
5) menentukan rentangan untuk masing-masing kategori-rentangan ditentukan dengan cara menghitung selisih skor tertinggi dikurangi dengan skor terendah dibagi dengan banyaknya kategori;

6) menetapkan skor masing-masing kategori menurut hasil perhitungan rentanganpenetapan skor masing-masing kategori dapat dimulai dari skor terendah atau skor tertinggi.

7) pemberian pemaknaan atau penafsiran terhadap skor-dalam memberikan pemaknaan atau penafsiran dengan cara mengonsultasikan dengan kriteria pada poin 6 sehingga dapat diketahui posisi skor pada rentangan yang ada.

Selain data dari penyebaran kuesioner dilakukan juga wawancara untuk mempertajam data dari hasil kuesioner. Dalam penelitian ini, peneliti mewawancari 3 mahasiswa, yaitu Ila dan Nada (fakultas pertanian) serta latif (fakultas kedokteran).

\section{HASIL DAN PEMBAHASAN}

Responden penelitian ini yaitu mahasiswa Strata Satu (S1) Unsoed angkatan 2014 dan 2015 dengan jumlah populasi 7376 orang dan 334 orang. Deskripsi responden penelitian dapat dilihat dalam Tabel 1.

Tabel 1. Deskripsi Responden Berdasarkan Fakultas

\begin{tabular}{|c|l|c|c|c|c|c|}
\hline No & \multicolumn{1}{|c|}{ Fakultas } & $\mathbf{2 0 1 4}$ & $\mathbf{2 0 1 5}$ & Jumlah & $\mathbf{\%}$ & Responden \\
\hline 1 & Pertanian & 552 & 536 & 1088 & $15 \%$ & 50 \\
\hline 2 & Biologi & 174 & 165 & 339 & $5 \%$ & 15 \\
\hline 3 & Ekonomi dan Bisnis & 532 & 622 & 1154 & $16 \%$ & 52 \\
\hline 4 & Peternakan & 268 & 249 & 517 & $7 \%$ & 23 \\
\hline 5 & Hukum & 384 & 388 & 772 & $10 \%$ & 35 \\
\hline 6 & FISIP & 397 & 426 & 823 & $11 \%$ & 37 \\
\hline 7 & Kedokteran & 165 & 164 & 329 & $4 \%$ & 15 \\
\hline 8 & Teknik & 232 & 256 & 488 & $7 \%$ & 22 \\
\hline 9 & Ilmu Kesehatan & 331 & 439 & 770 & $10 \%$ & 35 \\
\hline 10 & Ilmu Budaya & 214 & 244 & 458 & $6 \%$ & 21 \\
\hline 11 & MIPA & 153 & 186 & 339 & $5 \%$ & 15 \\
\hline 12 & PIK & 128 & 171 & 299 & $4 \%$ & 14 \\
\hline \multicolumn{7}{|c|}{ Total } \\
\hline
\end{tabular}

Pada Tabel 1 terlihat bahwa jumlah responden terbesar adalah mahasiswa Fakultas Ekonomi dan Bisnis Unsoed, yakni sebanyak 52 orang (16\%). Responden paling sedikit dari Fakultas Kedokteran dan Fakultas Perikanan dan Ilmu Kelautan, masing-masing sebanyak 14 orang (4\%). Data tersebut berdasarkan data penyebaran kuisioner kepada 334 mahasiswa S1 angkatan tahun 2014 dan 2015. Para responden dianggap telah melakukan aktivitas penulisan, baik menulis artikel maupun tugas-tugas terstruktur dalam proses perkuliahan. Pada aktivitas tersebut sangat terkait dengan proses pencarian, penelusuran, dan pemanfaatan sumber informasi dalam menyelesaikan tugas-tugas mahasiswa.

\subsection{Keterampilan dalam Menentuan Sifat dan Cakupan Informasi}

Indikator pertama dalam keterampilan literasi informasi, yaitu menentukan sifat dan cakupan informasi sesuai dengan pedoman penafsiran. Dari empat aspek keterampilan dalam menentukan sifat dan cakupan informasi yang dibutuhkan mahasiswa, diperoleh hasil penafsiran sebagai berikut (Tabel 2). 
Tabel 2. Deskripsi Penentuan Sifat dan Cakupan Informasi

\begin{tabular}{|l|c|c|c|c|c|}
\hline \multicolumn{1}{|c|}{ Kategori } & Nilai Interval & $\begin{array}{c}\text { Titik } \\
\text { Tengah }\end{array}$ & Frekuensi & Jumlah & Mean \\
\hline Sangat Trampil & $15,20-18,50$ & 16,85 & 309 & $5.206,65$ & \\
\cline { 1 - 5 } Trampil & $11,90-15,10$ & 13,50 & 770 & $10.395,00$ & \\
Cukup Trampil & $8,60-11,80$ & 10,20 & 212 & $2.162,40$ & \multirow{2}{*}{13,53} \\
\cline { 1 - 5 } Tidak Trampil & $6,30-8,50$ & 7,40 & 35 & 259,00 & \\
\cline { 1 - 5 } Sangat Tidak Terampil & $4,00-6,20$ & 5,10 & 10 & 51,00 & \\
\hline
\end{tabular}

Deskripsi keterampilan mahasiswa dalam menentukan sifat dan cakupan informasi yang dibutuhkan, terdiri dari empat aspek yang mendapatkan skor rata-rata 13,53. Hal tersebut termasuk dalam rentang 11,90 - 15,10 yang termasuk dalam kategori terampil. Dapat dipahami bahwa mahasiswa Unsoed terampil dalam menentukan sifat dan cakupan informasi yang dibutuhkan. Mahasiswa sudah seharusnya memiliki keterampilan untuk menentukan informasi yang sesuai dengan kebutuhannya. ACRL (2010) menyatakan bahwa mahasiswa yang sangat terampil akan mampu merumuskan terlebih dahulu langkah untuk memperoleh informasi, mengidentifikasi jenis dan ragam format informasi yang potensial, mempertimbangkan biaya dan keuntungan, serta mengevaluasi kembali sifat dan cakupan informasi yang dibutuhkan. Dari hasil analisis diketahui bahwa keterampilan mahasiswa dalam menentukan sifat dan cakupan informasi yang dibutuhkan termasuk kategori terampil.

Masih terdapat skor yang masih rendah dalam mengevaluasi kembali sifat dan cakupan informasi. Ila dan Latif mengatakan bahwa setelah memperoleh informasi tidak selalu melakukan evaluasi terhadap sifat dan cakupan informasi yang diperoleh karena tugas harus secepatnya dikumpulkan. Berbeda dengan Nada (mahasiswa yang sedang menyusun skripsi), jika mendapatkan informasi hasil penelitian akan membandingkan isinya dengan penelitian yang lain untuk informasi yang lebih lengkap dan valid. Naibaho (2015) mengatakan bahwa mahasiswa diharapkan dapat mengidentifikasi kata kunci sebagai akses poin dalam menelusur informasi. Kecakapan dalam merencanakan strategi penelusuran merupakan keterampilan dalam evaluasi sifat dan tingkat informasi untuk mengidentifikasi jenis dan keberadaan informasi.

Dalam menentukan sifat dan cakupan informasi, Latif, Nada, dan Ila menyatakan bahwa untuk menelusur informasi akan merumuskan langkah-langkah untuk mendapatkan informasi terlebih dahulu dan akan mengidentifikasi ragam format yang dibutuhkan. Mereka juga menyatakan bahwa biasanya mencari informasi melalui website dan buku. Terkait dengan biaya dan keuntungan dalam usaha untuk mencari informasi, Latif mengatakan bahwa waktu yang diperlukan untuk mencari informasi harus sesuai dengan informasi yang diperoleh agar waktunya efektif.

\subsection{Keterampilan dalam Mengakses Informasi secara Efektif dan Efisien}

Pada konteks ini, mahasiswa diharapkan dapat menempatkan hasil temuan dan menemukan informasi secara sesuai topik yang dipilih sehingga informasinya tepat dan akurat, baik ketika melakukan wawancara, studi lapangan, ataupun riset di luar kampus (Naibaho, 2015). Pada penelitian ini, keterampilan dalam mengakses informasi secara efektif dan efisien diukur menggunakan lima aspek indikator kinerja, sebagaimana tercantum dalam Tabel 3. 
Tabel 3. Deskripsi Mengakses informasi secara Efektif dan Efisien

\begin{tabular}{|l|c|c|c|c|c|}
\hline Kategori & Nilai Interval & $\begin{array}{c}\text { Titik } \\
\text { Tengah }\end{array}$ & Frekuensi & Jumlah & \multirow{2}{*}{ Mean } \\
\hline Sangat Trampil & $21,00-25,00$ & 23,00 & 359 & $8.257,00$ & \\
\cline { 1 - 5 } Trampil & $17,00-20,00$ & 18,50 & 850 & $15.725,00$ & \\
\cline { 1 - 5 } Cukup Trampil & $13.00-16.00$ & 14,50 & 381 & $5.524,50$ & \multirow{2}{*}{14} \\
\cline { 1 - 5 } Tidak Trampil & $9,00-12,00$ & 10,50 & 66 & 693,00 & \\
\cline { 1 - 5 } Sangat Tidak Terampil & $5,00-8,00$ & 6,50 & 14 & 91,00 & \\
\hline
\end{tabular}

Tabel 3 menunjukkan hasil perhitungan dari distribusi frekuensi keterampilan mahasiswa dalam mengakses informasi secara efektif dan efisien. Hasil tersebut diperoleh dari hasil perolehan data yang terdiri lima aspek keterampilan literasi informasi mahasiswa dan mendapatkan skor rata-rata 18,14. Berdasarkan pedoman pemaknaan skor 18,14 berada dalam rentang 17,00-20,00 termasuk dalam kategori terampil. Pangakses informasi kategori terampil dapat menerapkan strategi penelusuran dengan boolean operator sangat penting untuk melakukan penelusuran informasi. Selain itu, juga perlu melakukan penelusuran penggunaan metode penelusuran, seperti membatasi URL, tipe dokumen, dan mengevaluasi strategi penelusuran untuk mendapatkan informasi.

Berdasarkan pernyataan di atas dapat dikatakan bahwa keterampilan mahasiswa dalam mengakses informasi secara efektif dan efisien mendapat skor rata-rata masuk dalam kategori terampil. Dari data hasil wawancara terungkap bahwa dalam mengakses informasi secara online, mahasiswa tidak memilih metode penelusuran dan temu kembali informasi secara tepat dalam mencari informasi. Mahasiswa langsung mengakses Google bukan ke database jurnal ilmiah atau katalog perpustakaan/OPAC. Selain itu, mereka tidak menggunakan strategi pencarian informasi yang spesifik seperti menggunakan boolean operator atau membatasi URL.

\subsection{Keterampilan dalam Mengevaluasi Sumber-Sumber Informasi}

Keterampilan literasi informasi dalam hal mengevaluasi informasi dan sumbersumbernya secara kritis, ini diukur dengan 7 aspek indikator kinerja. Hasil perhitungannya terlihat pada Tabel 4.

Tabel 4. Deskripsi Keterampilan Mengevaluasi Sumber-Sumber Informasi

\begin{tabular}{|l|c|c|c|c|c|}
\hline \multicolumn{1}{|c|}{ Kategori } & Nilai Interval & Titik Tengah & Frekuensi & Jumlah & Mean \\
\hline Sangat Terampil & $31.00-35.00$ & 33,00 & 472 & $15.576,00$ & \\
\cline { 1 - 5 } Terampil & $25.00-30,00$ & 27,50 & 1248 & $34.320,00$ & \\
\cline { 1 - 5 } Cukup Terampil & $19,00-24.00$ & 22,00 & 560 & $12.320,00$ & \multirow{2}{*}{26,96} \\
\cline { 1 - 5 } Tidak Terampil & $13,00-18.00$ & 15,50 & 46 & 713,00 & \\
\cline { 1 - 5 } Sangat Tidak Terampil & $07,00-12,00$ & 9,50 & 12 & 114,00 & \\
\hline
\end{tabular}

Perhitungan yang terdapat pada Tabel 4 menunjukkan bahwa hasil perhitungan pada deskripsi frekuensi keterampilan mahasiswa dalam mengevaluasi informasi dan sumber-sumbernya secara kritis dan mendapatkan skor 26,96. Berdasarkan pedoman penafsiran, skor 26,96 masuk dalam rentang 25,00-30,00. Mahasiswa terampil dalam mengevaluasi informasi dan sumbersumbernya secara kritis harus ditingkatkan literasi informasinya. Almah (2010) mengatakan bahwa mahasiswa yang melek informasi dapat mengevaluasi informasi dan sumber-sumber informasi secara kritis dan menyatukan informasi terseleksi ke dalam pengetahuan dasarnya dan sistem nilainya. 
Latif mengatakan bahwa setelah mendapatkan informasi yang seseuai dengan kebutuhan, beberapa informasi tersebut akan dibaca untuk mendapatkan ide baru dan dikutip. Ila, Nada, dan Latif juga mengatakan bahwa akan melakukan perbandingan antara pengetahuan baru dan pengetahuan terdahulu agar dapat menentukan dan menemukan nilai tambah kontradiksi atau karakteristik unik lainya dari sebuah informasi. Hal tersebut untuk mendapatkan informasi yang valid serta untuk membuktian kebenaran pemahaman dan interpretasi informasi yang akan didiskusikan dengan dosen. Dalam hal terjadinya kesalahan query penelusuran informasi, menurut Latif perlu dilakukan perubahan kata kunci. Misalnya dengan menggunakan sinonim atau istilah lain yang memiliki pengertian sama dengan kata kunci yang digunakan dalam menelusur informasi.

\subsection{Keterampilan dalam Mengunakan Informasi}

Pemaknaan skor keterampilan mahasiswa dalam menggunakan informasi untuk tujuan tertentu diukur dengan menggunakan lima aspek, dan hasilnya dapat dilihat pada Tabel 5.

Tabel 5. Deskripsi Keterampilan Mahasiswa dalam Menggunakan Informasi

\begin{tabular}{|l|c|c|c|c|c|}
\hline \multicolumn{1}{|c|}{ Kategori } & Nilai Interval & $\begin{array}{c}\text { Titik } \\
\text { Tengah }\end{array}$ & Frekuensi & Jumlah & Mean \\
\hline Sangat Trampil & $21,00-25,00$ & 23,00 & 283 & $6.509,00$ & \\
\cline { 1 - 5 } Trampil & $17,00-20,00$ & 18,50 & 912 & $16.872,00$ & \\
\cline { 1 - 5 } Cukup Trampil & $13.00-16.00$ & 14,50 & 414 & $6.003,00$ & \\
\cline { 1 - 5 } Tidak Trampil & $9,00-12,00$ & 10,50 & 51 & 535,50 & \\
\cline { 1 - 5 } Sangat Tidak Terampil & $5,00-8,00$ & 6,50 & 9 & 58,50 & \\
\hline
\end{tabular}

Berdasarkan Tabel 5 terlihat bahwa keterampilan mahasiswa dalam menggunakan informasi untuk tujuan tertentu dijabarkan dalam lima aspek, dengan hasil skor rata-rata 17,96. Jika dilihat dari pedoman penafsiran, skor masuk dalam rentang 10,00-20,00, dengan kategori terampil. Latif mengatakan bahwa informasi yang diperoleh akan digunakan untuk mengerjakan tugas dari dosen, seperti membuat makalah atau menyelesaikan kasus yang diberikan oleh dosen. Hal tersebut menjadi cara yang efektif untuk mengkomunikasikan hasil karyanya. Latif, Ila, dan Nada juga mengatakan bahwa mahasiswa belum menggunakan reference manager untuk menyusun karya tulis dalam tugas perkuliahan.

\subsection{Keterampilan Mahasiswa dalam Aspek Ekonomi, Hukum, dan Sosial}

Pemaknaan terhadap skor keterampilan mahasiswa dalam memahami aspek ekonomi, hukum, dan sosial dalam penggunaan informasi ini diukur dengan menggunakan tiga aspek, sebagaimana dijelaskan pada Tabel 6 .

Tabel 6. Deskripsi Keterampilan Mahasiswa dalam

Memahami Aspek Ekonomi, Hukum, dan Sosial

\begin{tabular}{|c|c|c|c|c|c|}
\hline Kategori & Nilai Interval & Titik Tengah & Frekuensi & Jumlah & Mean \\
\hline Sangat Trampil & $13.00-15.00$ & 14,00 & 347 & $4.858,00$ & \multirow{5}{*}{12,02} \\
\hline Terampil & $10,50-12,90$ & 11,70 & 502 & $5.873,40$ & \\
\hline Cukup Trampil & $8,00-10,40$ & 9,20 & 125 & $1.150,00$ & \\
\hline Tidak Trampil & $5,50-7,90$ & 6,70 & 19 & 127,30 & \\
\hline Sangat Tidak Terampil & $3,00-5,40$ & 4,20 & 9 & 37,80 & \\
\hline
\end{tabular}


Dari hasil penghitungan, keterampilan mahasiswa dalam memahami aspek ekonomi, hukum, dan sosial dalam penggunaan informasi mendapat skor rata-rata 12,02. Jika dilihat dari pedoman penafsiran, skor 12,02 berada dalam rentang skor 10,50-12,90. Dapat dipahami bahwa mahasiswa termasuk dalam kategori terampil untuk memahami informasi dan sumbernya terkait dengan aspek ekonomi, hukum, dan sosial. Terkait isu privasi, Latif mengatakan bahwa isu privasi, hak akses informasi terkait dengan informasi sangat menjadi perhatian mahasiswa. Misalnya untuk mendapatkan informasi tentang rekam medis, mahasiswa harus menjaga informasinya dengan baik. Ila, Nada, dan Latif juga mengatakan bahwa privasi dalam penggunaan informasi perlu diperhatikan, terutama dalam hal mengutip karya orang lain

\subsection{Keterampilan Literasi Informasi Mahasiswa}

Hasil penelitian mengenai keterampilan literasi mahasiswa Unsoed terdiri dari lima Indikator kinerja Information Literacy Competency Standards for Higher Education ACRL, dan hasilnya dijelaskan pada Tabel 6 .

Tabel 6. Deskripsi Keterampilan Literasi Informasi Mahasiswa

\begin{tabular}{|c|c|c|c|c|c|}
\hline Kategori & Nilai Interval & $\begin{array}{c}\text { Titik } \\
\text { Tengah }\end{array}$ & Frekuensi & Jumlah & Mean \\
\hline Sangat Terampil & $1.405-1.670$ & $1.537,50$ & $1.651,00$ & $2.538 .412,50$ & \multirow{5}{*}{$1.251,06$} \\
\hline Terampil & $1.137-1.404$ & $1.270,50$ & $4.282,00$ & $5.440 .281,00$ & \\
\hline Cukup Terampil & $869-1.136$ & $1.002,50$ & $1.692,00$ & $1.696 .230,00$ & \\
\hline Tidak Terampil & $601-868$ & 734,50 & 217,00 & $159.386,50$ & \\
\hline Sangat Tidak Terampil & $334-601$ & 467,50 & 30,00 & $14.025,00$ & \\
\hline
\end{tabular}

Berdasarkan Tabel 6 dapat dikatakan bahwa keterampilan literasi informasi mahasiswa baru pada tingkatan terampil, yaitu dengan skor $1.251,06$. Kondisi tersebut harus ditingkatkan, karena penguasaan dan pemanfaatan informasi oleh seseorang akan berpengaruh pada tingkat kompetensinya. Mengacu pada Information Literacy Competency Standards for Higher Education diharapkan mahasiswa mampu menunjukkan indikator khusus untuk mengidentifikasi keterampilan literasi informasinya.

\section{KESIMPULAN}

Hasil penelitian menunjukkan bahwa keterampilan literasi informasi mahasiswa yang diukur melalui standar ACRL termasuk dalam kategori terampil. Berdasarkan hasil pengukuran kelima standar keterampilan literasi informasi, ada beberapa standar yang perlu ditingkatkan diantaranya: (1) standar kompetensi untuk menentukan sifat dan cakupan informasi yang skor rata-ratanya paling rendah $(3,73)$; (2) standar kompetensi untuk mengakses informasi secara efektif dan efisien $(3,88)$; dan (3) standar kompetensi untuk mengevaluasi informasi dan sumber-sumbernya $(3,84)$. Untuk meningkatkan keterampilan literasi informasi mahasiswa, perlu disusun program pembimbingan dan pelatihan dalam bentuk kelas literasi atau klinik literasi yang diselenggarakan secar periodik.

\section{UCAPAN TERIMA KASIH}

Penulis mengucapkan terima kasih banyak kepada Lembaga Penelitian dan Pengabdian Kepada Masyarakat (LPPM) Unsoed, khususnya kepada Ketua LPPM beserta jajarannya. 


\section{DAFTAR PUSTAKA}

ACRL. 2010. "Introduction to Information Literacy" 4: 22-25. Di http://www.ala.org/ala/mgrps/divs/acrl/ issues/infolit/overview/intro/index.cfm.

AL Hamidy, Yusuf Dzul Ikram, and Heriyanto. n.d. 2012. Kemampuan Literasi Informasi Mahasiswa pada Layanan American Corner di UPT Perpustakaan IAIN Walisongo Semarang Menurut Association of College and Research Libraries." Di http://www.ejournal3.undip.ac.id/index.php/lib/article/view/733779.

Almah, Hildawati. 2010. Information Literacy: Kecakapan Hidup dalam Era Post Modern. Iqra', 4 (1): 22-38.

CILIP. 2013. "Information Literacy." Di www.cilip.org.uk/cilip/advocacy_ campaigns/information-literacy.

Dangi, Ram Kumar, and Sanjiv Saraf. 2016. Information Literacy in Banaras Hindu University Library System. International Journal of Information Desemination and Technology 3 (6): 207-10.

Djaali. 2008. Psikologi Pendidikan. Jakarta: Bumi Aksara.

Doyle, Christina. 1992. "Outcome Measures for Information Literacy within the National Education Goal of 1990: Final Report of the National Forum on Information Literacy Summary of Finding." Di http://eric.ed.gov/ERICDocs/ data/ ericdoc2/content_storege_01/0000000b/80/23/4a/12/pdfl.

George, Hanna Chaterina. 2014. "Menuju Perpustakaan Sekolah Abad 21." Di http://sis.pahoa.sch.id/perpus/index.php?halaman=artikel_view\&id=20140326113402.

Hartinah, Sri. 2013. Metode Penelitian Perpustakaan. Tangerang: Universitas Terbuka.

Hasugian, Jonner. 2008. Urgensi Literasi Informasi dalam Kurikulum Berbasis Kompetensi di Perguruan Tinggi. Pustaha: Jurnal Studi Perpustakaan dan Informasi 4 (2): 34-44.

Naibaho, Kalarensi. 2015. Merancang Program Pendidikan Pemakai untuk Pemustaka Digital Native di Perpustakaan Universitas Indonesia. Visi Pustaka 17 (2): 96-109.

Nazir, Moh. 2009. Metode Penelitian. Jakarta: Ghalia Indonesia.

Pattah, Sitti Husaebah. 2014. Literasi Informasi: Peningkatan Kompetensi Informasi dalam Proses Pembelajaran. Khizanah Al Hikmah, 2 (2): 117-28.

Qalyubi, Syihabuddin, dkk. 2007. Dasar-Dasar Ilmu Perpustakaan dan Informasi. Yogyakarta: Fakultas Adab IAIN Sunan Kalijaga.

Rakhmat, Jalaluddin. 2000. Metode Penelitian Komunikasi. Bandung: Remaja Rosda Karya.

Septiyantono, Tri. 2014. Literasi Informasi. Tangerang: Universitas Terbuka.

Sinurat, Yohana Christy, Zulharman, and Rina Amtarina. 2017. Pola Keterampilan Literasi Informasi Proses Pembelajaran Problem-Based Learning pada Mahasiswa di Fakultas Kedokteran Universitas Riau. JOM FK 4 (2): 1-12. 
Sudarsono, Blasius. 2009. Pustakawan, Cinta dan Teknologi. Jakarta: Ikatan Sarjana Ilmu Perpustakaan dan Informasi Indonesia.

Sugiyono. 2010. Metode Penelitian Kuantitatif, Kualitatif, dan $R \& D$. Bandung: Alfabeta.

Sugiyono. 2014. Metode Penelitian Kombinasi (Mixed Methods). Bandung: Alfabeta.

Sukiman. 2011. Pengembangan Sistem Evaluasi. Yogyakarta: Insan Madani.

Sutabri. 2014. Pengantar Teknologi Informasi. Yogyakarta: Andi.

Tashakkori, Abbas, and Charles Teddlie. 2010. Mixed Metodologi. Yogyakarta: Pustaka Pelajar. 